\title{
SIMULATION AND ANALYSIS OF CAR NOISE POLLUTION IN THE TERRITORY OF KAUNAS UNIVERSITY OF APPLIED SCIENCES
}

\author{
Ina Bikuvienè $\dot{1}^{1}$ \\ Vytautè Juodkienè ${ }^{1}$ \\ 1 University of Applied Sciences, \\ Kaunas, Lithuania
}

Correspondence:

Ina Bikuvienè

e-mail:

ina.bikuviene@go.kauko.lt

\begin{abstract}
:
As the economy is growing, more and more families can afford to buy a car. The increasing number of cars means the increasing noise levels. After lots of scientific research, it was found that motor noise is harmful to human health. According to the existing laws, noise levels in residential areas during the day cannot exceed $65 \mathrm{~dB}(\mathrm{~A})$. Kaunas University Of Applied Science resides near one of the busiest streets in the city: Pramone avenue. There was an experiment carried out in April 2016 where the number of passing vehicles was counted. With ArcGIS software engine MapNoise using statistical functions and IDW, Spline and Kriging interpolation methods, transport noise analysis was carried out. The results showed that the average noise level varies between $55-65 \mathrm{~dB}(\mathrm{~A})$. The noise is significantly reduced by the trees and bushes growing near the School; without them the noise level would increase by about $5 \mathrm{~dB}(\mathrm{~A})$.
\end{abstract}

\section{Keywords:}

vehicle noise, modeling, GIS, MapNoise, geostatistical, IDW.

\section{INTRODUCTION}

In the last decades there has been a constant increase in the number of cars in the World and Lithuania. 1000 citizens in Lithuania had 185 cars in 1995, they had 340 cars in 2005 and in 2012 they had 541[17] cars. With the growth in the number of vehicles the influence of noise pollution to people's lives, surrounding and health increases as well. Noise pollution made by vehicles is currently said to be one of the most effective factors to humans' well-being $[2 ; 4 ; 8 ; 16]$. World health organization's (WHO) data shows [16] that over 200 million EU citizens (over half of the whole population) suffer from transport noise pollution. The allowed level of noise on working days (from 6AM to $6 \mathrm{PM}$ ) should not be higher than $65 \mathrm{~dB}$ [5]. Vehicle noise pollution effect on human's health is always mentioned in WHO and Europe environment agency's reports.

Over the past ten years various detailed analyses have been made about vehicle noise pollution in EU [13;16] and Lithuania [6]. Medical and scientific community has published many scientific articles and reports regarding vehicle noise pollution influence to human's health $[1 ; 5 ; 14 ; 16]$. Vehicle noise pollution level is based on few elements such as speed limit, 
amount and mobilization of cars, vehicle age, weight, driving manners - crossroads and traffic lights $[4 ; 10]$.

This problem is common in Lithuania, too. Starting from September $1^{\text {st }}, 2003$ in city and town areas the speed limit was reduced from $60 \mathrm{~km} / \mathrm{h}$ to $50 \mathrm{~km} / \mathrm{h}$. It is known that a reduction like this cuts noise level respectively to $2,1 \mathrm{~dB}(\mathrm{~A})[4 ; 10]$.There are various scientific studies made in Lithuania analyzing vehicle noise pollution $[2 ; 8 ; 10]$. In the science work report made in 2008 by VGTU [12] alongside other cities, Kaunas city traffic and noise level research in the main streets was included. The report showed that almost in every measurable area noise level exceeded the allowed $65 \mathrm{~dB}$ for residential properties. The University of Applied Sciences Kauno kolegija camp is near one of the busiest streets of the city- Pramones ave., where the traffic in the rush hour is especially intensive.

The map of Kaunas city noise level that was established in 2007 (Fig. 1.) also shows that the University of Applied Sciences Kauno kolegija camp is located in the zone that exceeds the allowed level of noise.

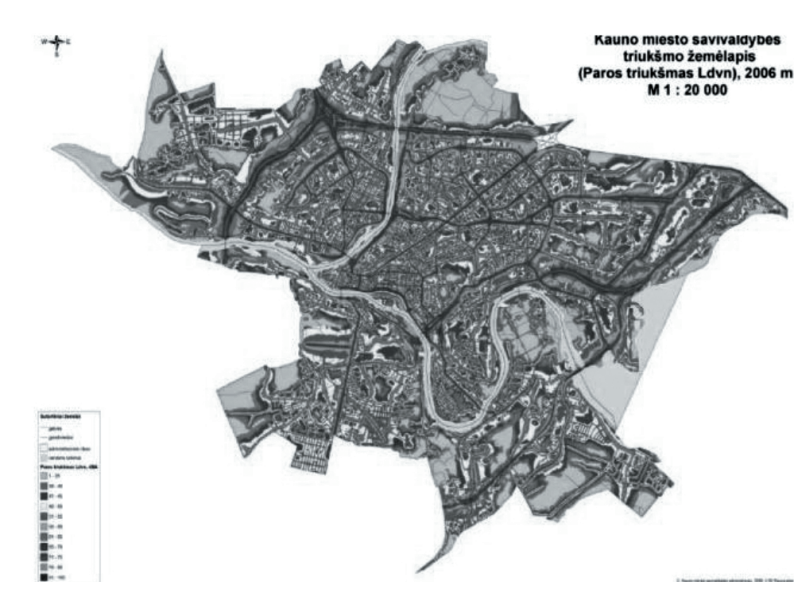

Fig. 1. The noise map of Kaunas city

After almost 10 years since the map was presented, the situation in the city has not improved, no new roads have emerged so that the traffic could be removed from residential properties or "smart traffic lights" which could help solve this issue. Quite the contrary - the number of vehicles has only grown and traffic time has only got longer possibly rising the level of vehicle noise pollution. Back in 1995 a 1000 Kaunas residents had 235 cars, in $2004-307$, in 2007 - 467 and in 2012 - 547 cars [16; 17].

The main goal of the research is to define vehicle noise pollution level in the University of Applied Sciences Kauno kolegija territory and its influence to students and employees. At the same time, the influence to noise level made by obstacles that naturally reduce noise level such as trees and other plants, was assessed.

\section{MATERIAL AND METHODS}

The research object - camp territory of the University of Applied Sciences Kauno kolegija, where the simulation of vehicle noise pollution was made.

Vehicle noise pollution measuring was made by using the annual average daily traffic (AADT) data (PI Roads and transport research institute). The annual average daily traffic in 2015 in Pramonès ave. included 23499 passengers' cars and 1705 heavy vehicles per day. Overall, AADT - 25204 vehicles per day. As additional source, monitoring results from April 2016 were used, when the measurements of traffic flow in Pramones ave. were taken from two different places towards the University of Applied Sciences Kauno kolegija (Fig. 2).

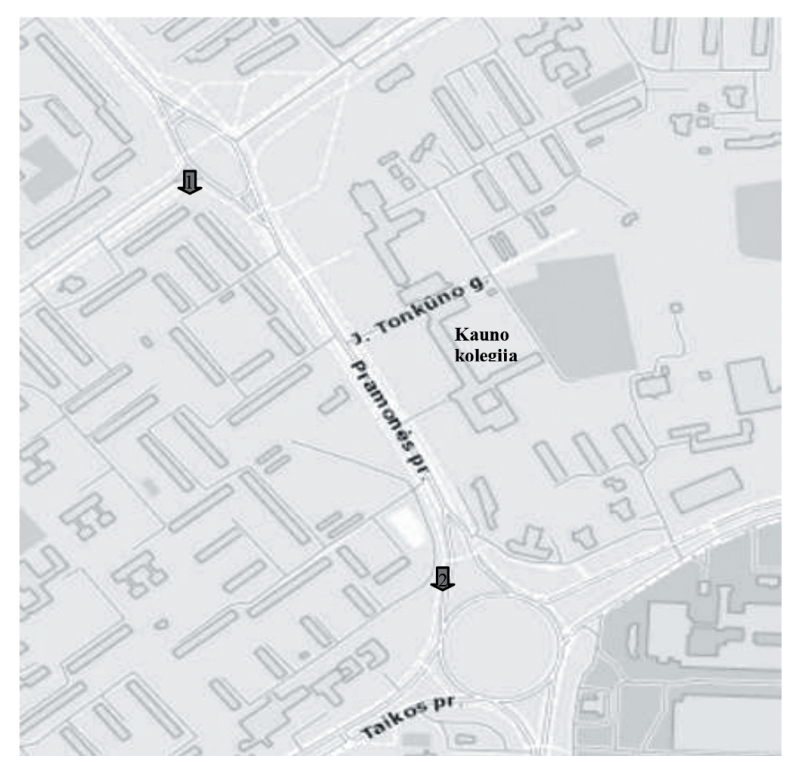

Fig. 2. Survey places around the University of Applied Sciences Kauno kolegija in April 2016.

While formatting the vehicle noise level emission map in ArcGIS software the following GIS data was entered: roads/streets, tall buildings, information about traffic flows with a percentage of heavy vehicles in the streets. At some points the noise level measurements were made during the day, the evening and the night. Day, evening and night noise level $\mathrm{L}_{d v n}$ in decibels $\mathrm{dB}(\mathrm{A})$ was calculated using the following formula: 
$L_{d v n}=10 \lg \frac{1}{24}\left(12 \times 10^{\frac{L_{\text {dienos }}}{10}}+4 \times 10^{\frac{L_{\text {vakaro }}+5}{10}}+8 \times 10^{\frac{L_{\text {nakties }}+10}{10}}\right)$

Here $\mathrm{L}_{\text {dienos }}$ - average long term A weighted noise level, set for one-year day time period, as defined [LST, 2004]; $\mathrm{L}_{\text {vakaro }}$ average long term A weighted noise level, set for one-year day evening period, $\mathrm{L}_{\text {nakties }}$ average long term A weighted noise level, set for one-year night time period [4].

If we wish to establish vehicle noise emission expressed by $\mathrm{L}_{d v n}$ using a software MapNoise, the amount of vehicles in daily traffic is entered $-\mathrm{Q}_{\text {dienos. }}$. Day and night vehicle noise emission is calculated [15], reduced traffic flow for day time (06-18 h.) $-\mathrm{Q}_{\text {dienosR }}$ and night time (22-06 h.) $-\mathrm{Q}_{\text {naktiesR }}$.

Reduced flow calculation formula:

$$
Q_{\text {dienos }}=Q_{\text {dienos_ah }} \cdot T_{d} \text { and } Q_{\text {nakties }}=Q_{\text {naktiess_ah }} \cdot T_{n}
$$

here $\mathrm{Q}_{\text {dienos }}$ - calculated traffic flow for a twelve hour day time; $\mathrm{Q}_{\text {nakties }}$ - calculated traffic flow for an eight hour night time; $\mathrm{Q}_{\text {dienos ah }}-$ calculated average hourly flow per day; $\mathrm{Q}_{\text {nakties_ah }}$ - calculated average hourly flow per night; $\mathrm{Td}$ - day time duration in hours [12]; $\mathrm{T}_{\mathrm{n}}$ - night time duration in hours [6].

The reduced traffic vehicle flow per day:

$$
Q_{\text {dienosR }}=24 / 12 \cdot Q_{\text {dienos }}
$$

The reduced traffic vehicle flow per night:

$$
Q_{\text {naktiesR }}=24 / 8 \cdot Q_{\text {nakties }}
$$

After traffic noise emission simulation, the results are verified according to noise subsistence measurement results. Such calculations are made with MapNoise software: surface calculations without relief, initial data check, configuration parameter set and the primary noise level are calculated by using annual average daily traffic coefficient (AADT). Vehicle noise emission will be evaluated with different interpolation methods: IDW, Spline and Kriging.

\section{VEHICLE NOISE EMISSION MODELING AND ANALYSIS}

While making the calculation all the effects of the roads and obstacles are considered at every point, in spite of their origin or material (landscape elements, various tall buildings, the existing or anticipated noise reduction barrier). Shielding and reflection effects are considered as well.

Since we are using ArcGIS software MapNoise package calculated results, it is possible to define the number of buildings that are in the noise impact zone, by grouping them according to the noise impact level.

Digital maps data (graphic data + tables with data in them) must be prepared in a particular format. The following data is evaluated:

- Buildings

- Plants that reduce noise

- Roads axial lines

- Radius selected for calculations

The determined point pollution is calculated by formula:

$$
H\left(s_{j}\right)=\sum_{N} \lambda_{i} H\left(S_{i}\right)
$$

here, $\mathrm{H}\left(s_{j}\right)$ - the set $s_{i}$. pollution value; $N$ - calculates the amount of points used; $\lambda_{i}$ - every measured point weight in decibels; $H\left(s_{i}\right)$ - the known pollution value in point $s_{i}$.

The point pollution $\mathrm{dB}(\mathrm{A})$ is calculated like this:

$$
\lambda_{i}=\frac{d_{i j}^{-p}}{\sum_{i=1}^{N} d_{i j}^{-p}}, \sum_{i=1}^{N} \lambda_{i}
$$

Increasing the distance, pollution is reduced because of category $P$ parameter effect; $\mathrm{d}_{i j}$ - the distance between determined point $s_{j}$ and measured $s_{i}$ points. By increasing the distance, the measured point effect for the determined point will be reduced exponentially (Fig. 3. a).The total pollution of calculation sites is equal to 1 .

By changing the $P$ parameter, it is possible to adjust the influence to relative selection sites. The increased parameter means that output meanings are more local, not calculated as all surrounding selection sites average value. By decreasing the parameter, the arithmetical value for average is being set, until all selection sites become identical, since further selection sites have higher effect.

\section{RESULTS AND DISCUSSION}

Interpolated pollution $\mathrm{dB}(\mathrm{A})$ allocation in the area evaluating geostatistical methods: IDW, Spline, Kriging. After evaluating pollution points average square bias 
a

Predicted $\cdot 10^{-2}$

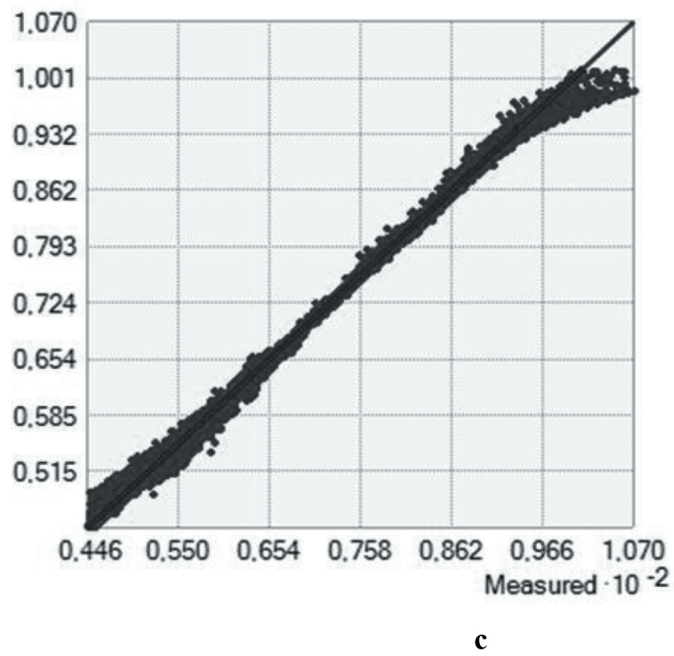

b

Predicted $\cdot 10^{-2}$

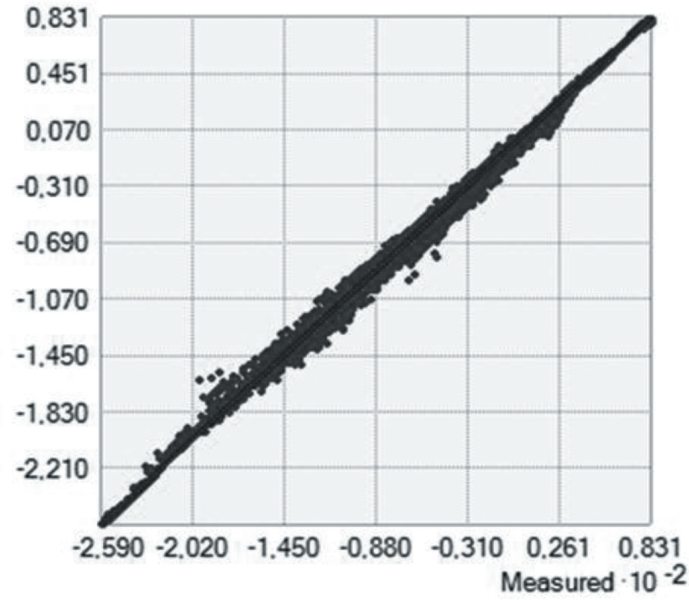

Predicted $\cdot 10^{-1}$

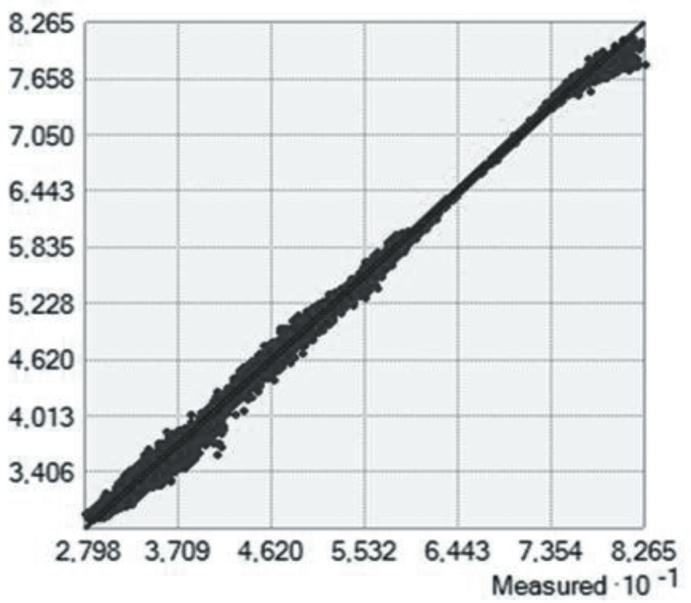

Fig. 3. The corresponding graph of semivariograms of interpolation methods: a) IDW, b) Spline, c) Kriging

(ASB), it's concluded that after interpolating with Kriging method the smallest ASB is - 0,38.
Meanwhile the least accurate is the Spline method, according to ASB - 1,52, and the standard square bias $-1,87$ (table 1 )

\begin{tabular}{ccccccc}
\hline $\begin{array}{c}\text { Interpolation } \\
\text { methods }\end{array}$ & $\begin{array}{c}\text { Samples, } \\
\text { dBA }\end{array}$ & Mean & $\begin{array}{c}\text { Root-Mean- } \\
\text { Square } \\
\text { Error[RMSE] }\end{array}$ & $\begin{array}{c}\text { Mean } \\
\text { Standardized }\end{array}$ & $\begin{array}{c}\text { Root-Mean- } \\
\text { Square } \\
\text { Standardized }\end{array}$ & $\begin{array}{c}\text { Average } \\
\text { Standard Error }\end{array}$ \\
\hline $\begin{array}{c}\text { Invert Distance } \\
\text { Weight [IDW] }\end{array}$ & 69276 & $-0,02$ & 0,58 & $-0,03$ & 1,64 & 0,47 \\
\hline Spline & 69276 & $-0,03$ & 1,52 & $-0,01$ & 1,0 & 1,87 \\
\hline Kriging & 69276 & $-0,01$ & 0,38 & $-0,01$ & 1,45 & 0,40 \\
\hline
\end{tabular}

Table 1. Noise dispersion [ $\mathrm{dBA}]$ distribution of interpolation methods

The received modeling results of noise level in the University of Applied Sciences Kauno kolegija camp by building facade from Pramones ave. side, show that the average daily level varies from 55 to $65 \mathrm{~dB}$ (A) (Fig. 4). 

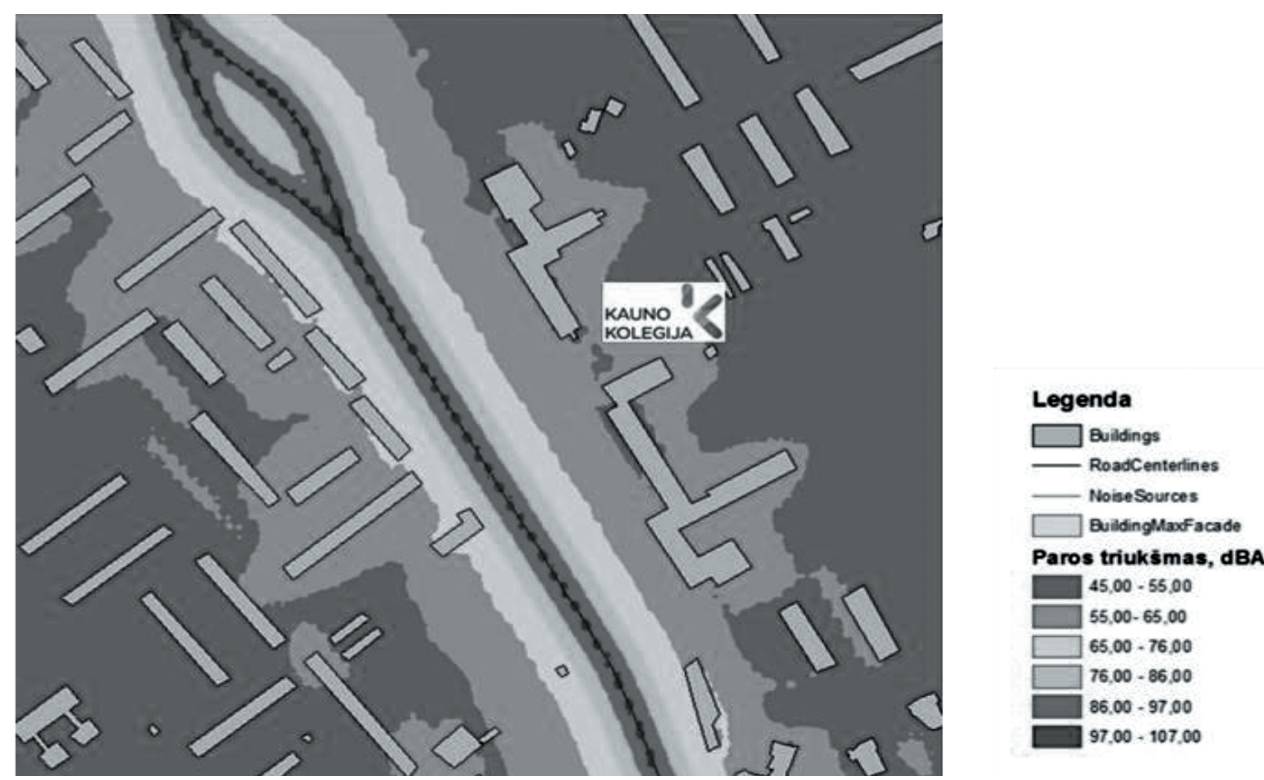

Fig. 4. The noise map of Kaunas University of Applied Sciences

Meanwhile the highest allowed noise level in residential properties and public purpose facilities, where the teaching or education takes place is $65 \mathrm{~dB}(\mathrm{~A})$. Interpreting research results it should be noted that the current noise level is significantly reduced with noise prevention tools noise absorbent barrier, such as plants and trees growing by the University of Applied science Kauno kolegija. After recalculating noise level without noise absorbent barrier, it's concluded that noise level would increase by $5 \mathrm{~dB}(\mathrm{~A})$.

The highest index of noise in the selected site is defined in V.Kreve - Pramone ave. round-about - $107 \mathrm{~dB}[\mathrm{~A}]$ (1st. monitoring site). It is supported with the conducted 2016 monitoring data, when in various day time intervals (79am, 11am-1 pm, and 3:30pm-5:30pm) the average vehicle amount in round-about towards the University of Applied Sciences Kauno kolegija from the site number one was - 6500 and from the site number two - 7200 vehicles. Influence on the increase of vehicle noise pollution is not only made by the increased number of vehicles, their age or weight, but also by raised speed limits and road surface coating interaction with tires. As additional noise reduction tools, the innovated road coating variations are considered - such as "silent asphalt" $[7 ; 18 ; 19]$.

Many other authors have conducted detailed research in the residential property line areas $[2 ; 8 ; 9]$. The most requested living and transport line separations are the plant (green) zones. Plants retain and absorb noise as a filter. They are the fastest absorbents of high frequency noises. The $7-8 \mathrm{~m}$. wide, dense tree and bush zones reduce noise by $6-7 \mathrm{~dB}(\mathrm{~A})$, and thick $40 \mathrm{~m}$. wide green zone - even 17-23 dB(A). Sparse $30 \mathrm{~m}$. wide zone reduces noise only by $8-11 \mathrm{~dB}(\mathrm{~A})$. Plants effectiveness for reducing noise in leafless period is decreased by $50-80 \%$. To reduce the noise and to comply with the sanitary norms there is a need of such a green line, that would be at least $50 \mathrm{~m}$. wide or even wider. Green lines along highways are arranged with the trees and bushes that are resistant to gas emission. Trees are planted in a way that treetops interlace and bushes are planted under the trees. The noise in the city can be reduced not only with the help of trees, but with the lawns and grass as well; they absorb sounds way better than asphalted surfaces and reduce the city background noise [3].

Therefore it is thought that in the nearest $20-25$ years in the biggest Middle and East Europe cities, due to vehicles, noise pollution will be increased by average $0,5-1$ $\mathrm{dB}(\mathrm{A})$ annually. If no action is taken to reduce the noise level, the $25 \%$ increase of vehicle flow will lead to the rise of noise level by $1 \mathrm{~dB}(\mathrm{~A})$.

\section{CONCLUSION}

1. The vehicle noise emission modeling is executed by entering GIS described data: traffic flow, speed, building height, heavy vehicle percentage in the traffic. The accuracy of interpolation is estimated by the cross testing method. It is determined that the IDW method is the most accurate, it results in average square bias $-0,47$. 
2. The University of Applied Sciences Kauno kolegija buildings do not exceed the level of noise that is in regulation for public purpose buildings (maximum noise level is $70 \mathrm{~dB}(\mathrm{~A})$ ); however, the residential properties near the University of Applied Sciences Kauno kolegija are in the zone where noise level significantly exceeds tolerated noise level (65-76 dB(A)).

3. It is concluded that the level of noise in the University of Applied Sciences Kauno kolegija is reduced by the surrounding plants and trees. Without the surrounding vegetation the noise level would rise by $5 \mathrm{~dB}(\mathrm{~A})$.

4. Noise pollution impact to the University of Applied Sciences Kauno kolegija employees and residents' health and living quality in the surrounding areas is indisputable and justifies a definite need for noise reduction tools.

5. In the residential properties, where noise level exceeds the edge of $69 \mathrm{~dB}(\mathrm{~A})$, noise reduction methods must be implemented.

\section{REFERENCES}

[1] Babisch, W., Beule, B., Schust, M., Kersten, N., Ising, H.,. Traffic Noise and Risk of Myocardial Infarction. Epidemiology 2005(16): pp. 33-40.

[2] Blažys, R., Garbinčius, G., Dabužinskaitė, Ž., Gedzevičius I. The research of traffic noise (Automobilių keliamo triukšmo tyrimai). Transport ingineering, vol.I(6), pp. 41-44, 2009

[3] Burinskienè, M.; Jakovlevas Mateckis,K.; Adomavičius, V. City planning (Miestotvarka). Vilnius. p. 446., 2003

[4] den Boer, L.C., A. Schroten, A.,. Traffic noise reduction in Europe. Report. Delft. 70, 2007

[5] For a number of vehicle noise limit values and the application of the Procedure for approval. 201311 13. Nr.V-499, Vilnius, 2013.

[6] Grazuleviciene R., Lekaviciute J., Deikus J., Mozgeris G., Merkevicius S.. Urban traffic noise and myocardial infarction risk. The 6 th international conference Environmental engineering. ISI proceedings. Vilnius, pp. 84-88., 2005

[7] Gidlöf-Gunnarsson, A., Öhrström, E.. The effectiveness of quiet asphalt and earth berm in reducing annoyances due to road traffic noise in a residential area. In Proceedins: 9th International Congress on Noise as a Public Health Problem [ICBEN] 2008, pp.631-639, ISBN 978-3-9808342-5-4
[8] Juodkienè V., Juškevičienè A. Analysis of vehicle traffic noise. Civil and Environmental Engineering. Vol. 8,(2), Slovakia. pp. 91 - 96, 2012.

[9] Klibavičius, A.. Vehicle pollution and its effects reduction (Transporto tarša ir jos poveikio mažinimas). City planning. Vilnius. pp. 341-363, 2000.

[10] Miškinyte, A., Dèdelè, A. Evaluation and analysis of traffic noise level in Kaunas city Proc. Of The 9th International Conference "ENVIRONMENTAL ENGINEERING” 22-23 May 2014, Vilnius, Lithuania. eISSN 2029-7092 / eISBN 978-609-457-640-9

[11] New EU vehicle noise limits. Briefing: 2012 04_TE Noise Position Paper_5pg_Final draft.

[12] Losses incurred due to the negative impact of the appreciation of the urban areas of the vehicle (Nuostoliu, patiriamų del neigiamo transporto poveikio urbanistinèse zonose, ịvertinimas) VGTU, Research work report,p.205, 2008.

[13] Stansfeld, S. A.; Matheson, M. P., Noise pollution: non-auditory effects on health, British Medical Bulletin 68: pp. 243-257, 2003. http://dx.doi. org $/ 10.1093 / \mathrm{bmb} / \operatorname{ldg} 033$

[14] The noise control law (Triukšmo valdymo istatymas). 20160512, . Nr. XII-2341, Vilnius.

[15] TemaNord: 1996:524: 0903-7004 Railway traffic noise: the Nordic. ISBN 9789291208371. p. 66

[16] WHO. Burden of disease from environmental noise. Quantification of healthy life years lost in Europe. Copenhagen: World Health Organization Regional Office for Europe. 106 p., 2011.

[17] Vilutienè, V., Ignatavičius, G., Jarmaliūnaite, V. Environment air pollution caused by vehickle and its research (Autotransporto sukeliama aplinkos oro tarša ir jos tyrimai). Vilnius, Proc. of Transport Management Problems Lithuania.. ISBN 9955-42357-9, pp. 135-158, 2006

[18] http://db1.stat.gov.lt/statbank/selectvarval/saveselections.asp? MainTable $=$ M7030305\&PLanguage $=$ $0 \&$ TableStyle $=\&$ Buttons $=\&$ PXSId $=3743 \& \mathrm{IQY}=\& \mathrm{~T}$ $\mathrm{C}=\& \mathrm{ST}=\mathrm{ST} \& \mathrm{rvar} 0=\& \mathrm{rvar} 1=\& \operatorname{rvar} 2=\& \mathrm{rvar} 3=\& \mathrm{rva}$ r4=\&rvar5=\&rvar6=\&rvar7=\&rvar8=\&rvar9=\&rva r10=\&rvar11=\&rvar12=\&rvar13=\&rvar14 [ online, .2017.02.13]

[19] http://asphaltmagazine.com/quiet-asphalta-choicefor-the-future/ [online, 2017.02.23]

[20] https://international.fhwa.dot.gov/pubs/quiet_pav/ pl05011.pdf [online, 2017.02.25] 